\title{
LINGUAGEM NATURAL E MÚSICA EM ROUSSEAU: A BUSCA DA EXPRESSIVIDADE
}

- RESUMO: As análises de Rousseau indicam que o ingresso no universo simbólico traz consigo a possibilidade da perda da unidade do indivíduo e com ela a possibilidade de ruptura do vínculo social. Partindo da demonstração que a mediação dos signos representativos dá-se em três instâncias distintas, procurou-se detectar se a mesma lógica que comanda o sistema como um todo subjaz às suas teorias musicais. A idéia de que uma seqüência hierarquizada de valores, que vão do mínimo ao máximo de inserção de signos representativos, também se exprime nas concepções musicais de Rousseau é aqui demonstrada, de modo que estas se integram perfeitamente ao conjunto da obra do autor por estarem em conformidade com os princípios que fundamentam suas doutrinas.

- PALAVRAS-CHAVE: Rousseau, música, linguagem, natureza.

Acompanhando-se as análises de Rousseau no segundo Discurso, no Emílio e no Ensaio sobre a Origem das Línguas, surge a suspeita de que se está diante de uma chave única que permitiria elucidar também a problemática musical: a noção de representação. Delineiam-se os contornos de uma hipótese plausível para dar conta da problemática da inserção das concepções de Rousseau sobre a música, no contexto maior de sua obra; pois assim como há uma recusa da representação nos diferentes planos em que se dá a perda de identidade do homem no decorrer de sua evolução, também na música esta recusa parece estar presente. Não apenas porque as análises do filósofo sobre o processo de evolução mental e intelectual do homem o atestam, mas também pela formulação direta de uma crítica aos signos representativos, presente em vários textos sobre a linguagem e a músi-

1 É Doutora em Filosofia pela Faculdade de Filosofia, Letras e Ciências Humanas da USP. 
ca. Neste texto, pretende-se demonstrar que a lógica que comanda as concepções musicais de Rousseau não difere daquela que comanda o sistema como um todo: a recusa da interposição dos signos representativos entre os homens e as próprias coisas.

As análises rousseaunianas acerca do ingresso do homem na vida social concebem-no como um processo de afastamento relativo à Natureza. Esse afastamento, que conduzirá à perda de sua identidade, efetua-se em pelo menos três instâncias distintas: no plano do raciocínio e do julgamento, no plano da atividade econômica e, por último, no plano da linguagem. ${ }^{2}$ Estes três níveis de análise evidenciam a ambição do filósofo: demonstrar que a mediação dos signos representativos que permeiam o modo de existir humano, nas sociedades contemporâneas, coloca em risco a unidade do ser social e, ao mesmo tempo, a autenticidade das relações humanas, que pode enfraquecer o vínculo social e comprometer a solidez do corpo político.

Todavia, para além da ambição do filósofo de suprimir tal mediação dos signos, está a consciência da impossibilidade de uma comunicação imediata entre os homens; a consciência de que no âmbito da vida humana a comunicação só pode se realizar por meio de sinais sensíveis. Esta necessidade de uma linguagem convencional deriva do caráter mediato do pensamento, já que, realizando-se por meio de conceitos e juízos encadeados, não pode exprimir-se imediatamente. O homem não pode prescindir do discurso, da sucessão e do encadeamento dos meios. Na ótica rousseauniana isto faz com que nosso saber seja sempre incompleto e nossa comunicação extremamente precária, pois como nossos pensamentos se transmitem sempre de maneira deformada, nossos sentimentos permanecem incompreensíveis para os outros. Exilado no mundo dos meios, o homem terá que passar necessariamente pela mediação dos sinais convencionais. Resulta daí a dificuldade de interpretar o pensamento desse homem de paradoxos. É neste contexto que se insere o sentido mais profundo das concepções musicais de Rousseau, pois não é a música um potente meio de comunicação, sobretudo quanto mais despojada de artifícios? A música é a "voz da natureza" (Rousseau, 1978, p.198), ela exprime diretamente as paixões sem passar pela mediação dos conceitos: "Os sons, na melodia, não agem em nós apenas como sons, mas como sinais de nossas afeições, de nossos sen-

2 O célebre Capítulo XV do Livro III do Contrato, denominado "Dos Deputados ou representantes" ilustra o aspecto político de sua recusa da representação. Nele, Rousseau se posiciona claramente a favor das formas diretas de exercício do poder por parte dos cidadãos. Também na arte "veremos os gêneros e as modalidades hierarquizados em função dos mesmos princípios e com base nos mesmos critérios de juízo que colocam sob suspeita a interposição mediadora e sedutora do representante a barrar o acesso à presença" (Salinas, 1997, p.30). 
timentos. Desse modo despertam em nós os movimentos que exprimem e cuja imagem neles reconhecemos" (Rousseau, 1978, p.191).

Se as "falsas artes" estão ligadas ao luxo e à corrupção que necessariamente as acompanha, a música, ao contrário, revela-se uma arte autêntica e adquire um lugar privilegiado na escala hierárquica dos valores expressivos por sua proximidade em relação à Natureza. Os poderes expressivos da arte são determinados, em Rousseau, segundo o seu grau de afastamento em relação à origem. Quanto mais afastada da natureza, maiores as chances de ter sua força expressiva comprometida, pois os signos representativos tendem a aí se introduzir. Buscar comunicar-se, segundo regras estabelecidas arbitrariamente ou mediante símbolos convencionais, é perder a espontaneidade, raiz da expansão do eu. O ingresso no universo simbólico traz consigo a possibilidade da perda de unidade de nosso próprio ser.

Nesse sentido, todo discurso, seja em língua falada ou escrita, tem a sua força expressiva comprometida. A arte musical surge no pensamento de Rousseau como condição essencial para a restauração da plena comunicação; ela não se restringe a proporcionar o prazer, - como já nos dizia o primeiro Discurso. Eis a razão do destaque atribuído à melodia, nas teorias musicais do filósofo, e à crítica empreendida no Ensaio às línguas destituídas dela, pois o valor ético se constitui na norma a partir da qual será julgado o valor estético. Se a melodia se converte em uma noção central, isto deriva da afinidade original entre linguagem musical e linguagem verbal. A melodia é a primeira linguagem e essa fusão entre música e poesia é que irá dotar a música antiga de um poder expressivo incomparável, como lemos no verbete "Música" da Enciclopédia: "... ela a seguia passo a passo, exprimindo exatamente o número e a medida e não se aplicava senão a lhe dar mais brilho e majestade". A admiração de Rousseau pela música grega antiga tem sua raiz não somente na crença de que ela reuniria elementos verbais e musicais de maneira simples e harmoniosa. Ele insiste sobre os efeitos da música sobre os povos gregos. ${ }^{3}$ Resulta daí a superioridade da música antiga como lemos no verbete música: "Eles [os gregos] não buscavam senão comover a alma, e nós só queremos agradar os ouvidos...".

A admiração do filósofo pela música (e, particularmente a música grega), para a qual nos chama a atenção Leduc-Fayette, em seu Jean-Jacques Rousseau e le mythe de l'Antiquité (Leduc-Fayette, 1974, p.121) revela que o valor estético da arte do músico não reside na sofisticação ou riqueza de seus artifícios técnicos, o que poderia parecer sinal de progresso, segundo a concepção de Rousseau, é sinônimo de regressão. Segundo Leduc-Fayet-

3 Efeitos "prodigiosos", segundo o Ensaio; "maravilhosos" e "surpreendentes" no verbete "Música". 
te esta arte é dotada de um privilégio raro, o de favorecer o deslocamento do indivíduo para um plano diverso daquele cujo domínio é o da imaginação e dos signos representativos. Quando projeta seu ideal de música sobre o modelo que julga ser o da música grega, o que Rousseau tem em vista é realçar a necessidade de se manter o homem afastado do sedutor mundo da perversão representativa.

Os elementos em torno dos quais ele constrói o seu ideal de música remetem à idéia de simplicidade, força (energia). ${ }^{4}$ A harmonia, tal como os modernos a inventaram, representa para ele, um empobrecimento, pois ela se sustenta da arbitrariedade de convenções que privam a música de seu poder expressivo, original, ligado à melodia. A harmonia indica a decadência que se abateu sobre o corpo social, pois toda música guarda estreita relação com a sociedade que a produz, como lemos no capítulo XIX do Ensaio.

Diante disso não é de estranhar o envolvimento do filósofo em uma série de polêmicas sobre questões musicais ao longo de sua vida. As disputas com Rameau, a defesa da melodia em detrimento da harmonia, a famosa querela dos bufões, os debates concernentes a Carta sobre a Música Francesa, são apenas alguns dos muitos pretextos usados por ele para defender com paixão desenfreada as idéias expostas em seus escritos de doutrina.

A recusa do excesso de artifícios também na música insere-se numa crítica mais ampla à sociedade do espetáculo, aquela que substitui a verdadeira essência das coisas pela aparência, como escreve no $3^{\circ}$ Diálogo. ${ }^{5}$ Não nos esqueçamos o tempo e lugar de onde nos fala Rousseau: uma Europa barroca dedicada a cultivar o gosto imoderado pelo luxo e a ostentação, pelo encobrimento do natural. Esse o olhar que o filósofo lança sobre a sociedade de seu tempo. Civilização que favorece a ampliação dos signos representativos e a passagem do campo do real para aquele do imaginário, em que os desejos se ampliam, engendrando objetos fictícios que se interpõem entre os homens e as coisas, os homens e os outros homens.

Assim, se a separação do homem de sua verdadeira essência e em relação ao demais resulta de sua imersão no mundo das instituições humanas, para se reencontrar, tornar-se ele mesmo, deve reconstruir seu pertencimento

4 A admiração de Rousseau pela música grega não deriva somente do seu poder de estreitar o laço social, mas de uma suposta função "pedagógica" de instruir e elevar as almas (Leduc-Fayette, 1974, p.121).

5 "Todos colocam seu ser no parecer". Ou, ainda, no primeiro Discurso, onde lemos: "Hoje, quando buscas mais sutis e um gosto mais fino reduziram a arte de agradar a princípios, reina em nossos costumes uma uniformidade vil e enganosa, e parece que todos os espíritos se fundiram num mesmo molde: incessantemente a polidez impõe, o decoro ordena; incessantemente seguem-se os uso e, nunca o próprio gênio. Não se ousa mais parecer o que se é..." (Rousseau, 1978, p.336). Veja-se também na $2^{a}$ parte da Nova Heloísa a Carta XVI (Rousseau, 1994, p.219) 
à ordem supra-individual, operando a síntese de sua particularidade e de sua inserção na coletividade. É precisamente esta busca de uma "transcendência imanente", de um caminho de emancipação do indivíduo que, no pensamento de Rousseau, constitui uma das dimensões subjacentes ao sentido mais profundo de uma crítica aos signos representativos, uma vez que eles corporificam a ruptura, o abismo criado entre a existência humana e a sua verdadeira essência. Se os descaminhos da civilização conduzem à alienação do ser social, a busca de uma forma de existência autêntica não está descartada. Liberado dos limites habituais, o homem pode acessar outros níveis de existência, que permitem atingir sua verdadeira natureza, sua condição originária de pureza e equilíbrio. Esta "liberação" é condição de expansão do próprio "eu" - e aqui não se trata do ego narcísico, que coloca em risco a unidade do corpo social, e sim da ampliação dos estreitos limites que encerram cada ser humano em seu solipsismo. A música é concebida como um instrumento potente de atuação sobre o estado de espírito humano, podendo desempenhar um papel análogo àquele que desempenha entre os antigos. Esta dimensão fortemente acentuada no pensamento de Rousseau é freqüentemente desprezada mediante o deslocamento do debate acerca de suas teorias musicais para o âmbito musicológico, enfatizando-se os aspectos técnicos.

No âmbito da música, as análises de Rousseau se exprimem numa dupla articulação entre a recusa dos signos representativos e a vinculação entre a música e a linguagem. Esse procedimento deve-se ao caráter antitético dos termos em questão: enquanto os primeiros exprimem o ingresso do homem no universo simbólico, a vinculação entre música e linguagem aponta para a origem. O par antitético natureza/artifício consiste assim, na base para a compreensão da lógica imanente às concepções teóricas de Rousseau, também no que concerne à linguagem e à música.

As concepções de Rousseau sobre a natureza e função da linguagem afastam-se sensivelmente do materialismo do século XVIII. Jean-Jacques reprova seus contemporâneos por "materializar as operações da alma", razão pela qual recusa-se a explicar a origem da linguagem pelo funcionamento de nossos órgãos ou pelas imposições de nossas necessidades físicas. Ademais, as premissas de que parte Condillac em seu Essai, isto é, as da existência de uma "espécie de sociedade estabelecida entre os inventores da linguagem" jamais poderiam ser aceitas por Rousseau, na medida em que isso corresponderia a julgar as origens em função do estado social. Em Rousseau a ordem social é concebida em oposição a um estado em que o homem é identificado com o residual decorrente da eliminação de todos os traços civilizados. É essa nova perspectiva que permite a Rousseau a recusa da noção do estado de natureza, tal como é formulada nas teorias contratualistas tradicionais, porque essa "falsa noção" conduz a uma concepção errônea do ato constitutivo da ordem social. Para Rousseau, os filósofos 
projetam sobre o homem natural atributos que pertencem exclusivamente ao homem civilizado. ${ }^{6}$ Por isso, na perspectiva de Rousseau, aceitar aquela afirmação de Condillac corresponderia a se colocar em contradição com sua tese fundamental.

O filósofo busca determinar - tanto no segundo Discurso como no Ensaio - se as operações cognitivas - razão, o entendimento - estão condicionadas à formação e desenvolvimento da linguagem ou, se essa última supõe desenvolvidas as faculdades intelectuais. No segundo Discurso, Rousseau estabelece a anterioridade do pensamento: não é a linguagem que cria o pensamento, mas o pensamento que serve de princípio à linguagem. A palavra, isto é, a linguagem articulada, elaborada mediante o concurso de signos de convenção, não constitui o primeiro estágio da linguagem; ela é uma aquisição tardia, resultado de um longo processo de evolução de nossas faculdades intelectuais. A língua primitiva, puramente instintiva e anterior às necessidades de comunicação se limitava a exprimir o grito da natureza: "A primeira língua do homem, a língua mais universal, a mais enérgica e a única de que necessitou antes de precisar persuadir homens reunidos, é o grito da natureza" (Rousseau, 1978, p.248). O abandono daquele estado de isolamento primitivo e a exigência daí decorrente de comunicação com os demais levam os homens a recorrerem à língua dos gestos e dos gritos inarticulados. A linguagem dos primeiros tempos é ao mesmo tempo visual e auditiva. A primeira consistia em designar os objetos pelos gestos, enquanto a linguagem auditiva se exprimia por meio das "inflexões da voz" e a emissão de "sons imitativos". ${ }^{7}$ Posteriormente, os homens inventam "sons articulados e convencionais" e esta substituição da linguagem primitiva pelos signos convencionais, isto é, a criação de uma linguagem mais adequada à representação do conteúdo das idéias está intimamente ligada à instituição da família e ao ingresso na vida social. No entanto, tais instituições apenas contribuem para desenvolvê-la e aperfeiçoá-la, porquanto a palavra tem uma origem natural, já que resulta de disposições presentes no homem desde a origem. Por esse motivo sua evolução é indiscernível das etapas de socialização do homem. E se, tal como a sociedade, a linguagem tende a corromper-se, a tornar-se mais e

6 É isso precisamente o que Rousseau critica em Hobbes; ou seja, a crítica se dirige não tanto à concepção hobbesiana de um estado de guerra total, mas à atribuição deste ao homem de natureza e não ao homem civil.

7 "Quando as idéias dos homens começaram a estender-se e a multiplicar-se, e se estabeleceu entre eles uma comunicação mais íntima, procuraram sinais mais numerosos e uma língua mais extensa; multiplicaram as inflexões da voz e juntaram-lhes gestos que, por sua natureza, são mais expressivos e cujo sentido depende menos de uma determinação anterior" (Rousseau 1978, p.248). 
mais pervertida quanto mais afastada da origem, sua instituição, por meio de sinais convencionais é como observa Eigeldinger "análoga ao contrato pelo qual são fixadas as relações entre os membros de uma mesma comunidade" (Eigeldinger, 1962, p.118).

Considerando que nesse estágio de desenvolvimento mental e intelectual, as faculdades intelectuais não estão plenamente desenvolvidas, o homem é incapaz de estabelecer categorias e ignora a propriedade das substâncias. Por isso, essa linguagem pronunciadamente musical e figurada, limitava-se a designar os seres e as coisas mediante o uso de termos particulares, sem estabelecer relações entre os objetos: "Cada objeto, a princípio, recebeu um nome particular, sem levar em consideração os gêneros e as espécies..." (Rousseau, 1978, p.248).

Resta explicar como poderia o primitivo elaborar noções abstratas se, nesse estado, está limitado a conceber imagens particulares em seu espírito. O problema do desenvolvimento da capacidade de abstração, que assegura o acesso às idéias gerais, tem em Rousseau, uma solução nominalista: são as palavras que permitem formar e traduzir as idéias gerais, como lemos no segundo Discurso: "As idéias gerais só podem introduzir-se no espírito com o auxílio das palavras e o entendimento só as aprende por via de proposições" (Rousseau, 1978, p.249). Como o primitivo limita-se a produzir imagens particulares em seu espírito, a linguagem torna-se o recurso por meio do qual serão produzidas as noções abstratas. ${ }^{8}$

Agora, com o ingresso no universo das idéias abstratas delineiam-se as condições favoráveis para a generalização e classificação dos elementos. Submetendo-se lentamente à ordem lógica - números, termos abstratos, conjugações dos verbos, regras da sintaxe - a linguagem tende a se tornar arbitrária, convencional. O contraste entre a aptidão da linguagem para traduzir as idéias e sua impotência em exprimir sentimentos, traduz a distância que a separa da linguagem natural dos primeiros tempos. E se a sua energia e intensidade primitivas cedem lugar à precisão e clareza, isso se deve à perfeita adequação da linguagem às exigências da razão e da sociedade.

Todavia, o problema da origem das línguas permanece intocado. O segundo Discurso não se propõe a resolver tais dificuldades relativas à lingua-

8 "Toda idéia geral é puramente intelectual e, por pouco que a imaginação nela se misture, a idéia logo se torna particular. Tentai traçar-vos a imagem de uma árvore em geral e jamais conseguireis; mesmo que não o queiras, será preciso vê-la pequena ou grande, pouco densa ou copada clara ou escura, e, se dependesse de vós nela não ver senão o que se encontra em todas as árvores, essa imagem já não se pareceria com uma árvore. Os seres puramente abstratos são assim vistos ou só se concebem pelo discurso. É preciso, portanto, enunciar proposições, é preciso falar para ter idéias gerais, pois, assim que a imaginação pára, o espírito só se movimenta à custa do discurso" (Rousseau, 1978, p.249) 
gem. ${ }^{9}$ Sem esboçar exatamente uma solução, o filósofo supõe que a linguagem seja um dom inato, um privilégio consentido por Deus, e o conjunto da obra o reafirma: a linguagem revela-se anterior à formação da sociedade e sua invenção explica-se por causas naturais.

Ora, se a linguagem é inata, como explicar que sua aquisição seja tardia? O que teria levado o homem a desenvolver uma linguagem visando comunicar-se com os seus semelhantes? Como compreender que as línguas sejam concebidas em Emílio como obras de arte, se a linguagem tem uma origem natural?

A solução do problema aparece de forma mais explícita na teoria da linguagem exposta no Ensaio. Mas ela supõe a distinção efetuada no Emílio entre uma "linguagem natural" e uma "linguagem de convenção" ou as línguas instituídas mediante signos representativos. A primeira concerne à forma de comunicação da criança e do primitivo, embora inarticulada esta forma de expressão é rica em acento, sonoridade, ritmo. A linguagem enquanto faculdade humana é natural. Essa linguagem que procede da natureza tanto pode ser gestual quanto vocal. Ela é uma aptidão que incita nossos órgãos a operar, comunicando nossas idéias, traduzindo nosso pensamento. Os órgãos, ao contrário do que afirmava Diderot, não criam a linguagem, ${ }^{10}$ mas é o poder inato da linguagem que os faz entrar em atividade. ${ }^{11}$

As línguas, ao contrário, invenções do gênio humano são linguagens artificiais, formas de expressão convencional criadas em função de necessidades decorrentes do desenvolvimento das instituições sociais. De certo modo, as línguas articuladas determinam a supressão, em maior ou menor grau, da linguagem universal. A perda dessa língua primitiva corresponde à perda do poder de comunicar, sobretudo, paixões e sentimentos, já que exteriorizando-se pela voz e pelo gesto, tinha o seu poder expressivo favorecido. Esse enorme poder de expressão da linguagem natural é descrito no

9 “... deixo, a quem o desejar, empreender a discussão desse problema difícil de saber o que foi mais necessário - a sociedade já organizada quando se instituíram as línguas, ou as línguas já inventadas quando se estabeleceu a sociedade" (Idem, p.250).

10 "A invenção da arte de comunicar nossas idéias depende menos dos órgãos que nos servem a esta comunicação do que de uma faculdade própria do homem, que o faz empregar seus órgãos com esse fim e que, caso lhe faltassem, o fariam empregar outros órgãos com o mesmo fim" (Rousseau, 1978, p.162).

11 A relação que se estabelece aqui entre a linguagem como faculdade inata e os nossos órgãos é análoga àquela relação estabelecida entre a perfectibilidade e as demais faculdades humanas. Ou seja, sem esta "faculdade da linguagem" nossos órgãos jamais teriam entrado em atividade; e, é por isso, que os homens se diferenciam dos animais. 
Livro I do Emílio, uma vez que, tal como o primitivo, a criança dela faz uso antes de adentrar ao universo simbólico. ${ }^{12}$

O texto acima referido fornece uma pista fecunda para se resolver a questão da origem da linguagem. Se a criança, assim como o homem do estado de isolamento primitivo, exprime-se perfeitamente através da linguagem natural dos gestos e da voz inarticulada e, se nesse estágio, ambos estão submetidos às necessidades físicas ou corporais, é de crer-se que a razão pela qual a linguagem convencional será criada esteja ligada a um outro tipo de necessidades. Antes de determinar esse tipo de necessidades que correspondem à instituição das línguas, e assim, apreender a razão pela qual elas foram concebidas pelo homem, vejamos a distinção entre a língua dos gestos e a língua dos sons.

A língua dos gestos é mais direta e por isso mesmo, mais expressiva. Sendo muscular atua sobre a imaginação por meio dos signos visuais, enquanto a língua dos sons, mais passional, favorece a comunicação afetiva e transmite com maior exatidão as marcas do sentimento.

Compreende-se agora o significado mais profundo das diferenças que essas duas formas de expressão guardam entre si. Os gestos exprimem as necessidades, enquanto as paixões e sentimentos se traduzem mais adequadamente mediante a linguagem da voz. Em outras palavras, a linguagem gestual deriva das necessidades físicas, ao passo que a linguagem articulada nasce da necessidade de comunicar paixões e sentimentos. A invenção da palavra se explica, portanto, pelas necessidades morais (besoins moraux). É precisamente esse tipo de necessidades que irá corresponder à instituição das línguas.

Submetido ao domínio das sensações, o homem primitivo vive em isolamento, de tal modo que uma comunicação calcada na língua dos gestos e no "grito da natureza" é capaz de satisfazer plenamente as exigências da conservação de si e da espécie. É somente quando passa a agir segundo princípios morais, que o homem é levado a elaborar uma forma de comunicação mais sofisticada, por meio da qual possa exprimir as necessidades

12 "À linguagem da voz junta-se a do gesto, não menos enérgica. Esse gesto não está nas débeis mãos das crianças, está em seus rostos. É espantoso como essas fisionomias que mal se formaram já têm expressão. Seus traços mudam de uma hora para outra com rapidez inconcebível; neles vedes o sorriso, o desejo, o terror nascerem e passarem como relâmpagos, e a cada vez credes ver um novo rosto... seus olhos opacos não dizem quase nada. Tal deve ser o gênero de seus sinais numa idade em que só têm necessidades corporais. A expressão das sensações está nas caretas e a expressão dos sentimentos está nos olhares". Grifo nosso (Rousseau, 1995, p.50). 
morais. ${ }^{13}$ Por isso, Rousseau rejeita as concepções que vinculam a invenção da palavra à expressão das necessidades físicas, como lemos no Capítulo II do Ensaio: "não se começou raciocinando, mas sentindo. Pretende-se que os homens inventaram a palavra para exprimir suas necessidades; tal opinião parece-me insustentável" (Rousseau, 1978, p.163).

Nessa perspectiva, a linguagem surge como um instrumento afetivo e moral, mas não se pode esquecer que apesar dessa origem, ela tende a se tornar utilitária e racional, pois sua evolução está associada ao desenvolvimento das instituições sociais. Com o exercício da reflexão, a linguagem tende a ampliar o universo de sua atuação. Por traduzir não apenas os sentimentos, mas, sobretudo, as idéias, ela se submete à inteligência e à razão em detrimento do coração. Todavia, se isso traz como conseqüência um acréscimo considerável na clareza e precisão na tradução do pensamento, por outro lado, sua virtude expressiva estará comprometida. Ao projetar-se no universo da representação, tornando-se um instrumento intelectual, ela empobrece.

A linguagem torna-se fria, um instrumento lógico submetido à mudança das idéias; sua carga afetiva e seu poder de encantamento são enfraquecidos, sua virtude musical e seu sentido metafórico são alterados. (Eigeldinger, 1962, p.163)

Convencido da degradação da linguagem, Rousseau se questiona sobre os elementos fundamentais da língua original. Haveria, afinal, um meio de reconquistar sua pureza primitiva, seu potencial expressivo?

No Ensaio, a descrição do momento em que nascem os primeiros sons emitidos pelo homem, formados segundo o gênero das paixões que se dese-

13 Esta solução aparece de forma mais explícita na teoria da linguagem exposta no Ensaio e fundase na distinção entre necessidades físicas e necessidades morais. As primeiras, permanecem no estado de natureza em perfeito equilíbrio com a capacidade de satisfazê-las, o que significa dizer que naquele estágio da vida humana, a língua universal - o grito da natureza - bastaria para uma comunicação que eventualmente se fizesse necessária. O homem só se vê impelido a se comunicar quando as necessidades morais o impõem. O advento da linguagem mantém com a moralidade relações intrínsecas. É somente quando passa a agir segundo princípios morais que o homem é levado a aperfeiçoar-se na arte da comunicação, criando uma linguagem mais complexa, mediante a instituição de símbolos representativos, isto é, sons articulados que prescindem de qualquer ligação evidente com os objetos representados. Nessa perspectiva, a função da linguagem seria originariamente expressiva: ela busca comunicar paixões e sentimentos e não apenas pensamentos, como nos diz o Ensaio: "Com as primeiras vozes formaram-se as primeiras articulações ou os primeiros sons, segundo o gênero das paixões que ditavam estes ou aqueles. A cólera arranca gritos ameaçadores, que a língua e o palato articulam, porém a voz da ternura, mais doce, é a glote que modifica, tornando-a em som. Sucede, apenas, que os acentos são nelas mais freqüentes ou mais raros, as inflexões mais ou menos agudas, segundo o sentimento que se acrescenta. Assim, com as sílabas nascem a cadência e os sons: a paixão faz falarem todos os órgãos e dá à voz todo o seu brilho; desse modo, os versos, os cantos e a palavra, têm origem comum" (Rousseau, 1978, p.186). 
java exprimir, já indicava implicitamente o princípio sobre o qual Rousseau iria estabelecer a origem da música e das línguas: o acento. Ele consiste na maneira por meio da qual as inflexões da voz são moduladas em função da variedade do sentimento de quem o exprime. A língua, a poesia e a música derivam das inflexões dos acentos, e por isso, sua virtude expressiva não poderia residir na natureza dos sons, mas na linha melódica do discurso. Em momento algum, afirma-se ser a música derivada das línguas articuladas, mas o contrário é verdadeiro: as línguas articuladas derivam de uma música originária e primitiva. Nos primeiros tempos "dizer e cantar eram o mesmo... falava-se tanto pelo som e pelo ritmo quanto pelas articulações e pelas vozes" (Rousseau, 1995, p.411). A primeira linguagem humana é poética e figurada; a prosa é posterior à poesia. "A primeira a nascer foi a linguagem figurada e o sentido próprio foi encontrado por último...a princípio só se falou pela poesia, só muito tempo depois é que se tratou de raciocinar" (Rousseau, 1978, p.164). O sentido figurado antecede o sentido próprio, assim como o sentimento nasce antes da razão. ${ }^{14}$ Respondendo a possíveis objeções, Rousseau explica, no Capítulo III do Ensaio, que a figura corresponde à tradução do sentido. Assim, para que a linguagem figurada tenha significado, é preciso transpor as palavras e as idéias: "Só se transpõem as palavras porque se transpõem também as idéias, pois de outro modo a linguagem figurada nada significaria" (Rousseau, 1978, p.164). Assim, se a primeira linguagem expreme-se mais diretamente, é por sua força figurativa. Eis porque só ela traduz os movimentos da paixão: é o emprego das figuras e das metáforas que garante seu caráter imediato.

Como foi observado por Eigeldinger, isso explica o poder expressivo da linguagem primitiva. Como as sensações estão ligadas a causas morais e aos sentimentos da alma, a linguagem figurativa e metafórica tem o seu poder de comunicar ampliado, pois as figuras das quais se utiliza reportam-se diretamente às sensações. Estas sensações não são puramente físicas, mas sensações representativas; e como "signos ou imagens" elas provocam afecções em nosso espírito, em nossa alma. Sendo assim, são as imagens aliadas ao traço metafórico da linguagem que a tornam altamente expressiva e que irão constituir sua poesia natural. ${ }^{15}$

14 Como lemos no Capítulo II do Ensaio: "Não se começou raciocinando, mas sentindo" (Rousseau, 1978, p.163)

15 O tema do "retorno às origens" perpassa toda a obra de Jean-Jacques, aparecendo, por vezes, explicitamente nos títulos, como no caso do Discurso sobre a origem e os fundamentos da desigualdade entre os homens e no Ensaio sobre a origem das línguas; e ainda, de modo implícito como na Profissão de Fé, em que se procura compreender a crise moral e religiosa a partir de nossas "disposições primitivas", para citar apenas um exemplo. O tema é objeto de uma análise minuciosa efetuada por Baczko no capítulo intitulado "La "Nature" et l'idée de l'histoire" de sua obra Solitude et Communauté 
Mas, se a poesia e a música têm uma origem comum, a língua primitiva não é apenas poética, mas também musical: "A paixão comunica à linguagem uma medida, um ritmo e as inflexões semelhantes àquelas da melodia. O sentimento se exprime por figuras, mas igualmente pelos sons e pelos signos auditivos" (Eigeldinger, 1962, p.124). Na origem, a melodia estava incorporada à linguagem, cabendo a ela dotar a palavra de sua intensidade, ou como quer Rousseau, cabe a ela dotar a palavra de energia. ${ }^{16}$ Assim como a metáfora, a melodia traduz o ímpeto da paixão e as afecções da alma, pois assim como as imagens, os sons agem em nós como sinais de nossas afeições, de nossos sentimentos. A função simbólica essencial de traduzir os impulsos da paixão atribuída à melodia faz dela o elemento unificador da música e da poesia, essa linguagem natural dos primeiros tempos. Essa união da poesia e da música, traço marcante das línguas antigas, como a dos gregos, ${ }^{17}$ tende a ser rompida com o desenvolvimento da razão analítica e o do elemento técnico e racional da música, a harmonia; música e língua somente se separam quando do advento da civilização.

Para Rousseau, a língua degenera quando se torna lógica; a música quando instaura o predomínio da harmonia. A linguagem articulada tende a afastar-se gradualmente da língua espontânea e direta dos primeiros tempos mediante a perda de sons e ritmos. Eis porque a perda de seu poder de comunicação imediata é atribuída à ausência do acento, pois somente ele parte diretamente das paixões, sem passar pela mediação dos conceitos.

À perda irreversível de expressividade que a linguagem conhece no decorrer de sua evolução, alia-se o seu caráter convencional. ${ }^{18} \mathrm{O}$ aspecto nefasto desse traço convencional que ela adquire, reside no fato de a introdução dos signos operar a passagem para a esfera da representação. Isso corresponde a um considerável afastamento da origem, uma vez que exprimir-se segundo regras estabelecidas é perder a espontaneidade que está na raiz da expansão do eu, condição de possibilidade para a superação da cisão que submete o homem social.

16 Veremos mais adiante que se trata de um conceito essencial no contexto da teoria da linguagem.

17 "Uma língua que não tenha, pois, senão articulações e vozes, possui somente a metade de sua riqueza; na verdade, transmite idéias, mas para transmitir sentimentos e imagens, necessitam-se ainda de ritmos e sons, isto é, de uma melodia: eis o que a língua grega possui, e falta à nossa" (Rousseau, 1978, p.187).

18 O caráter convencional da linguagem é assim descrito no segundo Discurso: "... resolveram então substituí-lo pelas articulações da voz que, sem ter a mesma relação com certas idéias, são mais apropriadas a representá-las como sinais instituídos. Tal substituição só pôde fazer-se com o consentimento comum, de maneira bastante difícil para ser praticada por homens cujos órgãos grosseiros não possuíam ainda qualquer exercício, sendo esta substituição mais difícil de conceber-se em si mesma, posto que aquele acordo unânime teve que ser motivado..." (Rousseau, 1978, p.248). 
Do mesmo modo como a razão analítica se impõe à linguagem, tornando-a imprópria para a expressão dos sentimentos. A harmonia compromete na música a potência expressiva da melodia. Assim, está configurada a ruptura entre a língua e a música. Uma vez imersas no universo da representação, esta separação tende a se acentuar provocando uma dupla degeneração. Não apenas a palavra perde o poder de comunicar, como a música deixa de exprimir nossos autênticos sentimentos.

"Antes dessa ruptura, introduzida pelo progresso da técnica e da análise, a linguagem associava naturalmente a poesia e a música, a metáfora e o ritmo" (Eigeldinger, 1962, p.125). Nessa arte em que a palavra cede lugar à melodia, o predomínio das sensações, tanto as físicas como as representativas, tem como conseqüência a eliminação do amor-próprio narcisista.

Todavia, a atuação do pensamento lógico sobre a linguagem não se restringe a um aspecto puramente negativo. Se a razão suprime a energia do discurso e enfraquece o poder de expressão, por outro lado, implica também um acréscimo de conhecimentos que conduzirão ao desenvolvimento da civilização. Assim sendo, cabe-nos indagar o porquê da insistência de Rousseau em enfatizar as qualidades da linguagem primitiva, considerando-se, sobretudo, que a condição do homem civilizado é irreversível. O retorno ao estado de natureza não é apenas impossível como ainda indesejável (Baczko, 1974, p.138)

Embora o estilo apaixonado de alguns textos rousseaunianos nos leve a apreender "passagens nostálgicas" em sua obra, não há dúvida que para Jean-Jacques, a linguagem original consiste mais exatamente num modelo a partir do qual será julgado o nível de corrupção ou degeneração das línguas. É a proximidade ou afastamento de uma língua em relação à língua originária que determina seu poder expressivo. Quanto mais próxima da origem, maior o poder que possui para comunicar paixões e sentimentos.

Afinal, o que se entende por "origem" quando se fala da primeira forma de linguagem? A linguagem da origem é aquela rica em figuras, em sons e ritmos; está de tal forma impregnada de melodia que não é possível distinguir música e poesia: elas são uma e mesma coisa. A interpretação do pensamento desse homem de paradoxos estaria mais uma vez equivocada, se julgássemos que trata-se apenas de mera nostalgia da língua original. Aparentemente sem importância, essa questão, na verdade, é essencial, ${ }^{19}$ visto

19 Pressupor uma nostalgia da origem pode conduzir a uma interpretação como aquelas que inspiraram mitos de "retorno" à natureza, considerando a obra de Rousseau como uma idealização do homem primitivo, do "bom selvagem". Ao longo dos anos, os comentadores de Rousseau têm demonstrado que a hipótese do estado de natureza se constitui numa construção metodológica e historiosófica que, desempenha uma função essencial na doutrina do filósofo. 
que ela traduz a busca de uma categoria em virtude da qual a relação ao outro não mais conduzisse à oposição dos homens entre si. Uma busca cujo termo estará na substituição da palavra por linguagens mais diretas, como a música e a dança.

Para conhecer os desdobramentos dessa problemática, impõe-se delimitar o espaço no qual se desenvolvem as análises de Rousseau acerca dos problemas da comunicação - o que nos remete, por um lado, ao Ensaio sobre a Origem das Línguas e, por outro lado, ao conjunto de textos nos quais elaboram-se as concepções de música, notadamente os artigos "Imitação, "Medida", "Ritmo" e "Sonata", do Dicionário de Música.

No Ensaio, a tentativa de encontrar uma categoria que transcendesse a mediação nas relações interindividuais, representa uma inversão da perspectiva adotada no segundo Discurso. Trata-se de especificar as necessidades que correspondem à instituição da linguagem por meio de sinais convencionais. Nessa nova perspectiva, a história da linguagem torna-se via de acesso a uma análise dos problemas da linguagem, cujo núcleo é o tema da degradação da língua como sintoma da degeneração do corpo social. A alteração da língua surge como a manifestação de uma degradação levada, a efeito, no campo social e político. A língua exprime a decadência que abateu-se sobre o corpo social; ela nada mais faz do que torná-la manifesta. Esse desvelamento por ela operado, qual seja, tornar explícita a corrupção da sociedade, em princípio, supõe uma estreita ligação entre dois domínios, a língua e a esfera política: a alteração da língua é inseparável da corrupção da sociedade.

Mas, se a língua "torna visível o invisível", se, paradoxalmente, desnuda o mal político por meio da deformação de si mesma, convertendo-se desde então, no "mal lingüístico", cabe indagar a que se deve esta sua performance. O estatuto singular que Rousseau lhe atribui deve ser creditado ao fato de ser ela uma conseqüência direta da degeneração da sociedade, como forma de expressão por excelência do homem civilizado, ou antes, por ter a língua um lugar privilegiado em todo o processo de socialização do homem, desde a origem até a degeneração da sociedade?

Ainda que, não se pretenda trazer à luz a polêmica acerca das circunstâncias de elaboração do Ensaio e sua relação com o Ensaio sobre os Conhecimentos Humanos de Condillac (1746) e o Comentaire de Duclos, obras que estariam em sua raiz, não podemos nos furtar em reconhecer nessa última, a idéia de uma concomitante deterioração lingüística e política. A noção de degeneração da língua ali exposta, não esconde uma abordagem mais próxima daquela posteriormente apresentada por Rousseau, uma vez que parte da constatação de uma inclinação "que temos em tornar nossa língua branda, afeminada e monótona. Temos razão - nos diz Duclos - em evitar a rudeza na pronúncia, mas creio que caímos no defeito oposto. Antigamente pronunciávamos muito mais ditongos que hoje ... esses ditongos colocavam 
força e variedade na pronúncia, salvando-a de uma espécie de monotonia que vem, em parte, do excesso de es mudos" ${ }^{20}$ Como não pensar na Carta sobre a Música francesa, na qual as dificuldades que envolvem a música francesa são associadas à debilidade da própria língua? No texto da referida Carta, que antecede aquele em que Rousseau aplica-se a analisar as conseqüências de uma música derivada da língua francesa (ainda não nomeadas explicitamente), lemos: "Pode-se conceber algumas línguas mais próprias à música que outras; pode-se conceber uma que não seja própria à música. Tal língua seria composta por sons mistos, sílabas mudas, surdas ou nasais, poucas vogais sonoras, muitas consoantes e articulações, à qual faltariam ainda outras condições essenciais das quais falarei no artigo medida" (Rousseau, 1995, p.292). A censura à monotonia da língua, presente também em Duclos e em outras obras de Rousseau, de modo mais explícito remonta a uma longa tradição, conforme nos indica Starobinski na notas à Carta sobre a Música francesa da edição da Pléiade (p.1454-1455), da qual derivar-se-á a antítese monotonia/energia. Essa reprovação já aparece em Mersenne: "os italianos representam a paixão com uma violência estranha (...); nossos franceses usam de uma doçura perpétua em seus cantos, o que impede a energia"; ${ }^{21}$ e em Lecerf Viéville: "Não é necessário diminuir o efeito das dissonâncias pelo uso freqüente como fazem os italianos; mas é preciso evitar cair no excesso contrário, a monotonia que os italianos poderiam nos reprovar", 22 para citar apenas dois autores. A conotação que adquire a noção de força ou energia, quando aplicada à retórica do sublime no século XVIII, não pode ser ignorada: ela é concebida como energeia do discurso e, por vezes, como enargeia ou figuração forte. ${ }^{23}$ No artigo "Énergie, force" da Encyclopedie, lemos: "Parece que energia diz ainda mais que força e se aplica principalmente aos discursos que pintam (peignent)" ${ }^{24}$ Seguindo a mesma via proposta pela tradição, Rousseau irá concebê-la como o princípio sem o qual, tanto a música quanto a palavra, terão seu potencial expressivo comprometido. Isso explica o motivo pelo qual a música puramente harmônica será preterida, uma vez que destituída dessa energia. Não obstante, a vantagem de efetuar o que é impossível fazer com a voz, a música instrumental, para atingir a condição de arte imitativa, necessita recorrer à

20 Comentaire de M. Duclos apresentado na seguinte edição: Grammaire Génerale et Raisonée de Port-Royal de Armand e Lancelot precedida pelo Essai sur l'origine et les progrès de la langue française de M. Petitot, Perlet, An XI - 1803.

21 O texto é citado por Borrel, L'interprétation de la musique française: de Lully à la Revolution, F Alcan, 1934, p.145

22 Veja-se J.-L Lecerf de la Viéville, Comparasion de la musique italienne et la musique françoise, 1704-1706, éd. De Bruxelas, 1755, chaps. XX.

23 No primeiro caso, veremos que mantém estreita ligação com a noção de acento.

24 Veja-se, verbete "Énergie, Force", Encyclopédie. 
palavra, de onde irá retirar seu vigor, sua energia, como lemos no verbete "Sonata" do Dicionário de Música. ${ }^{25}$ Na Dissertação sobre a Música Moderna, a energia da língua aparece, uma vez mais, associada à capacidade de exprimir: "uma língua enérgica" é "mais fácil de entender e, por isso, tornase universal ..." (Rousseau, 1995, p. 159).

A noção de energia adquire - não só no que concerne à palavra, mas também à música - um papel fundamental na transmissão de paixões e sentimentos; sua ausência constitui-se num fator impeditivo da plena comunicação. Como atestam os textos até aqui apresentados, a energia de uma língua determina seu grau de deterioração, de tal modo que, uma língua branda, composta por poucos ditongos, vogais mudas, e exposta, por assim dizer, ao mal da monotonia revelar-se-á corrompida ou, dependendo das circunstâncias, suscetível de corromper-se, visto que tais características redundam inevitavelmente, segundo a ótica rousseauniana, numa debilidade comunicativa. Todavia, se a deterioração da língua é passível de ser traduzida em ausência de energia não estaríamos diante do princípio que buscávamos e que deveria fornecer a chave para a compreensão daquilo que torna a língua corrompida? Mas, se a energia é o princípio que buscávamos e que deveria explicar a deterioração da língua, essa energia precisa ser definida. O que torna uma língua enérgica, expressiva e, portanto, própria à música?

Afinal, em que consiste essa energia? Para defini-la é preciso apreciar sua referência a uma noção sobre a qual, Rousseau estabelece a origem da música e das línguas: o acento, a maneira por meio da qual as inflexões da voz são moduladas em função da variedade de sentimentos de quem o exprime, como nos diz o Ensaio na descrição do momento em que nascem os primeiros sons emitidos pelo homem, os quais se formaram segundo o gênero das paixões que se desejava exprimir. ${ }^{26}$

25 "A música puramente harmônica é pouca coisa; para agradar constantemente e prevenir o tédio (ennui - que aqui tem uma forte conotação de 'monotonia'), ela deve se elevar à classe das artes da imitação; mas sua imitação não é sempre imediata como a da poesia e da pintura; a palavra é o meio pelo qual a música determina freqüentemente o objeto do qual ela nos oferece a imagem e é pelos sons tocantes da voz humana que essa imagem desperta, no fundo do coração, o sentimento que deve produzir. Quem não sente quanto a pura sinfonia, na qual se procura fazer brilhar o instrumento está longe desta energia? Todas as loucuras do violino de M. De Mondonville me enternecerão (attendriront) como dois sons da voz de Mademoiselle le Maure. A sinfonia anima o canto e acrescenta à sua expressão, mas não o substitui" (Rousseau, 1995, p.1060).

26 Nas notas ao Essai, das Obras Completas de Rousseau, edição de La Pléiade, Starobinski nos diz que a origem comum da música, da poesia e das línguas preconizada por Rousseau não seria, no século XVIII tão original. No prefácio acrescentado em 1729 a Oedipe (1718), Voltaire assim se manifesta: “... os primeiros filósofos, os legisladores, os fundadores das religiões e os historiadores eram todos poetas". Diderot, por sua vez, afirma que "a boa música é vizinha da língua primitiva" (O.C.,T. XIII, p.800), proposição, aliás, implicitamente referendada por Rousseau que a amplia e aprofunda. Conforme Starobinski, notas ao Essai, O.C., Pl., T.V. 
Eis porque somente os acentos podem assegurar uma comunicação imediata e autêntica: partem diretamente das paixões sem passar pela mediação dos conceitos, razão pela qual a ausência de som e ritmo, ou em outras palavras, a ausência de vogais e ditongos e o excesso de vogais mudas, corresponde à fragilidade da língua, à sua impotência em exprimir. Em conseqüência de sua derivação das inflexões dos acentos, a língua não poderia ter sua virtude expressiva retirada da natureza dos sons, mas da linha melódica do discurso. A riqueza de uma língua reside, pois, na sua melodia, visto serem os sons e os ritmos, seus elementos constitutivos: "Uma língua que não tenha, pois, senão articulações e vozes possui somente a metade de sua riqueza; na verdade, transmite idéias, mas, para transmitir sentimentos e imagens, necessitam-se ainda de ritmos e sons, isto é, de uma melodia: eis o que a língua grega possui, e falta à nossa" (Rousseau, 1995, p.411). Compreende-se agora o que subjaz à deterioração de uma língua: a carência de melodia.

A melodia é, precisamente, a "energia" da qual estão despojadas as línguas modernas, princípio que determina em geral a primazia da música vocal sobre a instrumental e, em particular, as críticas dirigidas à música francesa (na Carta sobre a Música Francesa), por resultar de uma língua desprovida de energia.

Finalmente, se a exigência de desvendar o princípio que permitia a Rousseau afirmar a deterioração das línguas modernas conduziu ao estabelecimento da melodia como alicerce de toda língua que se pretenda enérgica, expressiva, própria à música, impõe-se agora compreender o que levou Rousseau a associar aquela deterioração à da sociedade. Para dar conta do problema da vinculação da deterioração da língua à degradação da sociedade é preciso recorrer uma vez mais à tese esboçada por Duclos, na obra citada anteriormente Remarques sur La Grammaire Générale et Raisonée.

Após referir-se à displicência na pronúncia própria à impaciência de se exprimir, da qual deriva a alteração da natureza das palavras e, criticar as mutilações das palavras, as elisões, Duclos acrescenta:

temos muito mais palavras abreviadas ou alteradas pelo uso do que se acredita. Nossa língua torna-se insensivelmente mais própria à conversa que à tribuna; a conversa dá o tom ao púlpito, ao barrote, ao teatro, enquanto nos gregos e nos romanos, a tribuna não se submetia a ela. Uma pronúncia permanente e uma prosódia fixa e distinta devem se conservar particularmente nos povos que são obrigados a tratar publicamente matérias do interesse de todos os ouvintes porque ... um orador cuja pronúncia é firme e variada deve ser entendido mais longe que outro... ${ }^{27}$

27 No Ensaio sobre a Origem das Línguas, Rousseau comenta vários trechos da obra de Duclos, chegando mesmo a afirmar que "O sr. Duclos não reconhece qualquer acento musical em nossa língua, mas unicamente o acento prosódico e o vocal" (Rousseau, 1978, p.172). 
Nesse modelo de relações sociais que inspira Duclos - a democracia ateniense e romana -, o domínio da língua corresponde ao domínio que estes povos têm de si mesmos. Sendo um dos caracteres definidores do grupo social, a língua deve manter sua integridade como condição para que a liberdade se perpetue. A mutação da língua resulta da dispersão do povo e corresponde à perda do poder que este exerce sobre si mesmo, ao início, portanto, de sua sujeição a outrem. Não é difícil perceber a proximidade da ótica a partir da qual Rousseau concebe o problema da linguagem. A diluição de uma língua na perda de seu potencial expressivo representa para a coletividade a perda de sua própria identidade, uma vez que na língua estão reunidos os caracteres próprios de uma nação. A língua é o modo de expressão por excelência de toda uma cultura, de tal modo que, preservar a integridade da língua é resguardar os valores definidores do corpo social. Ao tornarem-se impotentes para exprimir os verdadeiros sentimentos, as palavras deformam as relações entre os homens, deixando de ser o sustentáculo da comunicação autêntica, da qual depende a consolidação do vínculo social.

Ao restituir à palavra a sua melodia, tal como na origem, o canto restabelece as condições para a superação da separação entre os indivíduos. Assim, se nas festas rousseaunianas ${ }^{28}$ a música vocal tem primazia sobre a instrumental e, representa em certa medida a recusa da palavra, é porque adquire um estatuto singular, de uma arte que tem sua presença assegurada na instauração do vínculo social.

Se nossa condição de existência está investida de obstáculos aparentemente intransponíveis, pressupor que pudesse ser superada seria admitir a possibilidade de criação de uma nova dimensão em que as relações entre os homens pudessem ser subvertidas mediante formas de expressão mais autênticas. Essas formas de expressão supõem, assim, uma linguagem mais tocante, mais expressiva que a linguagem racional. Uma linguagem capaz de transcender a dimensão em que se desenvolvem as relações sociais e atingir o nosso "eu" autêntico e, por isso, capaz de criar uma comunicação imediata.

28 As críticas de Rousseau à própria essência da sociedade contemporânea nas análises do processo de exteriorização do homem deixam entrever a possibilidade de uma restauração da unidade do corpo social e do indivíduo através das festas populares. A festa opera uma subversão radical na vida cotidiana: o "olhar do outro" já não nos inspira o secreto desejo de distinção dos demais, mas se converte agora num elemento indispensável à preservação da transparência das relações entre a pessoa humana e a totalidade social. A mediação monetária é substituída pela espontaneidade de uma alegria que prescinde do luxo e da ostentação. A imaginação liberada do desejo, dispensada da tarefa de auxiliar o entendimento na produção do conhecimento, pode agora abandonarse ao deleite do prazer estético que a música e a dança proporcionam. Finalmente, a palavra torna-se um acessório que tende a ser suprimido, afinal, como manteria perante a música e a dança o poder de comunicar sentimentos? Assim, se a festa se impõe como o paradigma da comunidade política é porque satisfaz a exigência de eliminar tanto quanto possível da esfera das relações sociais toda a mediação, que, no limite, exprime-se numa crítica aos signos representativos. 
A música converte-se assim, no acesso a uma nova identidade, a um novo modo de existência possível por meio da eliminação dos signos, que são separados de seus referentes sensíveis. A reabilitação da palavra realiza-se sob uma nova ótica; agora ela se faz por intermédio do canto. Pois, afinal, não é o canto que está em sua origem? Lembremo-nos das palavras do Ensaio: "nos primeiros tempos, dizer e cantar era o mesmo...". A restauração da palavra faz-se aqui através da música. A música irá revesti-la da expressividade necessária. Transformada em canto, a palavra apossa-se da melodia e recupera o poder de comunicar. Compreende-se, agora, o lugar que ocupa na teoria da linguagem a noção de "linguagem original"; ele é análogo àquele que a música terá no interior do sistema. É porque passa sem ruptura do objeto ao sinal que o exprime, que a linguagem dos primeiros tempos constituir-se-á numa espécie de paradigma a toda e qualquer forma de comunicação que se pretenda expressiva. Da mesma forma, a música, segundo concebe Rousseau, estabelece uma relação imediata, uma correspondência direta entre os sentimentos que se pretende traduzir e os sons e ritmos que os transmitem. Ela não apenas elimina a separação, mas promove uma verdadeira identidade. ${ }^{29}$ Suprimindo ao máximo os signos representativos engendrados pelo raciocínio lógico, pela palavra, pela escrita e recorrendo a sinais que promovem, no plano do sentimento, um fenômeno análogo, a música transmuta-se na forma de comunicação por excelência. Assim, se Rousseau critica as línguas modernas e a música fundada na predominância da harmonia, é por terem elas perdido seu caráter imediato, por sua impotência em impedir a separação que instala-se entre o sinal que representa e o objeto representado.

Enfim, pela inserção e multiplicação de signos representativos que colocam em risco a autenticidade da comunicação. Trata-se de uma recusa da representação também no plano da linguagem, pois quanto maior a diversidade e complexidade dos signos convencionais, ou em outras palavras, quanto maior nossa distância da linguagem figurativa e metafórica dos primeiros tempos, maior o risco de degeneração das relações humanas. Se o homem social está submetido a uma dupla cisão, que o faz viver simultaneamente em dois planos inconciliáveis, como são o mundo social e o mundo interior (traduzidos pela antítese aparência/essência), como poderia exprimir-se para além desta divisão? Através da razão e da palavra ele só poderá exprimir-se a partir de uma mesma lógica, a lógica da representação e, por isso também, no âmbito da linguagem, progresso não é sinônimo de desenvolvimento moral.

29 "Enquanto a linguagem racional é de origem utilitária e profana, a linguagem dos signos preserva o sagrado e respeita o sentido religioso do objeto. Ela produz na ordem do sentimento um fenômeno análogo" (Eigeldinger, 1962, p.126). 
FREITAS, Jacira de. Natural language and music in Rousseau: the quest for expressiveness. Trans/Form/Ação, (São Paulo), v.31(1), 2008, p.53-72.

- ABSTRACT: Rousseau's analysis indicates that the entrance in the symbolic universe brings the possibility of loosing individual's unity, what may induce the rupture of social bond. Considering the demonstration that the representative signs mediation takes place in three different instances, we tried to detect if the same logic that commands Rousseau's system as a whole is also verified in his musical theories. Here we demonstrate that Rousseau's musical conceptions, expressed through a hierarchical sequence of values going from minimum to maximum insertion of representative signs, are perfectly integrated in the author's work, agreeing with the principles on which his doctrines are based.

- KEYWORDS: Rousseau, music, language, nature.

\section{Referências bibliográficas}

BACZKO, B. Rousseau: solitude et communauté. Tradução do polonês por ClaireBrendek-Lamnhout. Paris: Mouton, 1974.

BAUD-BOVY, S. Rousseau Musicien. In: J.-J. ROUSSEAU. Neuchâtel: La Baconnière, 1988.

EIGELDINGER, M. Jean-Jacques Rousseau et la réalité de l'imaginaire. Neuchâtel: La Baconnière, 1962.

LEDUC-FAYETTE, D. Jean-Jacques Rousseau et le mythe de l'Antiquité. Paris: J. Vrin, 1974

MARQUES, J. O. A. "A educação musical do Emílio". Rapsódia - Almanaque de Filosofia e Arte. São Paulo: Departamento de Filosofia-USP, 2002.

ROUSSEAU, J.-J. Oeuvres Complètes. Paris: Gallimard, Bibliothèque de la Pléiade, v.I (1959), v.II (1961), v.III (1964), v.IV (1969), v.V (1995).

Ensaio sobre a origem das línguas. São Paulo: Abril Cultural, 1978. (Coleção Os Pensadores).

Emílio ou Da Educação. São Paulo: Martins Fontes, 1995.

Júlia ou a Nova Heloísa. Campinas: Hucitec/Ed. Unicamp, 1994.

STAROBINSKI, J. Introdução e notas à "Lettre à D'Alembert". In: ROUSSEAU, J.-J. Oeuvres Complètes. Paris: Gallimard, Bibliothèque de la Pléiade, v.V, 1995.

VIÉVILLE, J.-L. Lecerf de la. Comparación de la musique italienne et la musique françoise, 1704-1706. Éd. De Bruxelas, 1755, chap. XX.

SNYDERS, G. Le gôut musical en France. Paris: Vrin, 1968.

DELON, M. L'idée de énergie au tournant des lumières (1770-1821). Paris: Presses Universitaires de France, 1987. 